ISSN 0258-7122

Bangladesh J. Agril. Res. 38(4): 705-717, December 2013

\title{
VARIABILITY, CORRELATION AND PATH ANALYSIS IN LABLAB BEAN (Lablab purpureus L.)
}

\author{
M. SALIM ${ }^{1}$, S. HOSSAIN $^{2}$, S. ALAM ${ }^{3}$ \\ J. A. RASHID ${ }^{4}$ AND S. ISLAM ${ }^{5}$
}

\begin{abstract}
The results of the study carried out during 2009-2010 with lablab bean (Lablab purpureus) are presented in this paper. Data were recorded from all experimental plants on the following characters as number of pods/plant, pod yield/plant (g), number of seeds/pod, number of seeds/plant; seed yield/plant (g), Range, mean, genetic parameter, correlation co-efficient and path coefficient were studied. High heritability coupled with high expected genetic advance in percentage of mean were observed for most of the characters. The coefficients of correlation showed that seed yield/plant was positively and significantly correlated with days to first flowering, days to $50 \%$ flowering, days to first pod setting, number of pods/plant, pod yield/plant and seeds/pod, number of seeds/plant, and seed yield. Path coefficient analysis showed that days to first flowering, days to 50\% flowering, number of pods/plant, 20 pod weight (g), pod yield/plant, pod length, number of seeds/pod, number of seeds/plant, 100-seed weight influenced seed yield/plant directly in positive direction. Among the characters, number of seeds/plant had high positive correlation with seed yield/plant. Days to first pod setting exhibited negative direct effects on seed yield. From this result, it can be concluded that days to first flowering, days to $50 \%$ flowering, number of pods/plant, pod yield/plant, number of seeds/pod, number of seeds/plant, 100-seed weight are the most important yield contributing characters as they influenced pod yield and seed yield directly in positive direction.
\end{abstract}

Keywords: Lablab been, genetic parameters, correlation coefficient, and path coefficient.

\section{Introduction}

Lablab bean [Lablab purpureus (L.) Sweet; hitherto Dolichos lablab], commonly known as country bean or deshi sheem in Bangladesh, is a highly proteineous legume and a major winter vegetable. Lablab bean can be grown in a wide range of soil with average fertility like other beans (Nath, 1976). Generally, it is cultivated as annual or biennial crop. This bean is considered as one of the oldest cultivated crops of the world (Bullivant,1963). It is believed to have originated in

\footnotetext{
${ }^{1 \& 2}$ Scientific Officer, Hill Agricultural Research Station, Bangladesh Agricultural Research Institute (BARI), Khagrachari, ${ }^{3}$ Scientific Officer, Regional Agricultural Research Station, Akbarpur, Moulivi Bazar, ${ }^{4}$ Research and Development Officer, MATEX, Foundation, Gazipur, ${ }^{5}$ M.S Student, Dept. of Agronomy, Bangladesh Agricultural University (BAU), Mymensingh, Bangladesh.
} 
Indian subcontinent (Nath, 1976; Purseglove, 1977; Yamaguchi, 1983; Chakravarty, 1986; Katyal and Chandha, 1988; and Chowdhury et al., 1989). In Bangladesh, Chittagong and coastal regions are, especially reputed for its cultivation (CFLIP, 1988). In Bangladesh, it has many local names, such as Chhoi, Uri, Ushi as well as Sheem (CFLIP, 1988). The production of bean in our country was 83 thousand metric tons during 2006-2007.

The average yield of lablab bean in Bangladesh is very low (4.8 tons per hectare) compared to that (10 t/ha) in global context. This low yield status is attributed to the lack of prescribed production practices and lack of high potential varieties. Most of the varieties grown in Bangladesh are photoperiod sensitive and timely fixed with indeterminate growth habit. They only flower and produce edible pods during winter season under short day length.

Heritability estimates excluding the genotype-sowing date interaction, variation from the total variance would be more appropriate for prediction of genetic advance upon selection. Information on the genetic advance of yield components and correlation coefficients among themselves from the same population under differential sowing conditions is of practical crop breeding implication. From this paper, we have tried to find out the important genetic parameters relevant to pod yield and useful traits and examine interrelationship among characters contributing to pod and seed yield.

\section{Materials and Method}

The experimental plot was located at the Genetics and Plant Breeding Experimental Farm, Bangladesh Agricultural University (BAU), Mymensingh, and the period was from August 2009 to April 2010. Sixty-six climbing genotypes were used in the experiment. The seeds were collected from the Lablab Bean Research Programme of Genetics and Plant Breeding Department, BAU. The materials included a number of advanced lines along with parental genotypes and land races. The experimental plots were prepared by digging pits about one week before sowing. Pits were spaced $2.0 \mathrm{~m}$ both between rows and within rows. Each pit was fertilized with $10.0 \mathrm{~g}$ Urea, $30.0 \mathrm{~g}$ TSP (Triple Super Phosphate), and $20.0 \mathrm{~g}$ MP (Muriate of Potash). Fertilizers were well mixed with the soil of the pits. The design was RCB with three replications. The seeds were sown on 14 August 2009. In each pit, 3 to 4 seeds were sown, but only one plant retained after germination. The young growing plant was supported by a single bamboo stake in each pit. Weeding was done at 25 and 50 days after sowing. Harvesting of green edible pods was started in the 2nd week of January 2010 and continued up to middle of April 2010. Data were recorded from all experimental plants on days to first flowering, days to $50 \%$ flowering, days to first pod setting, number of pods/plant, 20-pod weight (g), pod yield/plant (g), pod length $(\mathrm{cm})$, number of seeds/pod, number of seeds/plant, 100-seed weight (g), seed 
yield/plant (g), range, mean, genetic parameter, correlation coefficient, and path coefficient analysis.

\section{Results and Discussion}

Genetic parameters, such as the genotypic variance $\left(\sigma^{2}\right)$, phenotypic variance $\left(\begin{array}{c}\sigma^{2} \\ \mathrm{p}\end{array}\right)$, genotypic coefficient of variation (GCV), phenotypic coefficient of variation (PCV), heritability $\left(\mathrm{h}^{2}{ }_{\mathrm{b}}\right)$, expected genetic advance (GA), and expected genetic advance in percentage of mean (GA\%) were estimated for all the characters under study (Table 2). The heritability was categorized as suggested by Robinson et al. (1949), while genetic advance by Johnson et al. (1955). All the characters showed marked differences between GCV and PCV estimates indicating that substantial variation for these characters was contributed by environmental components. Seed yield/plant had the highest GCV (66.39\%). Most of the characters displayed high heritability in the study. These high heritabilities might be attributed to genetic diversity and variation. Days to first flowering (DF) had high heritability (97.99\%) with limited GCV (16.04\%); similar result was observed by Rahman (1989). Kabir and Sen (1987) also found high heritability $\left({ }_{\mathrm{h} b}^{2}\right)$ for days to flowering. Further, DF (Days to flowering) showed moderate GA in percentage of mean (32.71\%). Days to first pod setting showed high heritability with low GCV and moderate GA. This result indicated that selection for days to first pod setting within these genotypes might not be effective. In the present study, number of seeds/pod had moderately low $\mathrm{h}^{2} \mathrm{~b}$ (35.40\%) with moderately low GCV (13.88\%) and moderately low GA (17.01\%). Rahman et al. (1988) reported low heritability coupled with low genetic gain for number of seeds/pod. The values of genotypic and phenotypic coefficients of variation for seed yield/plant were high $66.39 \%$ and $70.37 \%$, respectively, and the difference between those was low suggesting limited influence of the environment for the expression of this character.

Very high estimates of both $\mathrm{h}^{2}{ }_{\mathrm{b}}(99.92 \%)$ and genetic advance (132.98\%) registered for number of pods/plants suggesting that this character was predominantly controlled by additive genes, therefore, highly heritable. Nahar and Newaz (2005) also found similar results; Rahman (1989) observed very high $\mathrm{h}^{2}{ }_{\mathrm{b}}$ coupled with high GCV for number of pods/plant. Pod yield/plant also displayed high $\mathrm{h}_{\mathrm{b}}^{2}$ (99.87\%), high GA (130.07\%), and GCV (63.18\%). The high estimates of these genetic parameters suggested that pod yield/plant was genetically controlled with little environmental influence. Similar results were observed by Nahar and Newaz (2005). Twenty green pod weight displayed negligible difference between GCV and PCV suggesting environment had little effect for its expression. The high $h^{2}{ }_{b}(98.08 \%)$ estimate coupled with high GA (52.62\%) indicated the involvement of additive genes for the control of this character. Ali et al. (2005) found high heritability for pod weight. The moderately high $\mathrm{h}_{\mathrm{b}}^{2}(76.64 \%)$ coupled with moderately high GA $(42.13 \%)$ in pod 
Table 1. Estimates of genetic parameters for yield and yield contributing characters of 66 genotypes of lablab bean.

\begin{tabular}{|c|c|c|c|c|c|c|c|}
\hline Characters & $\begin{array}{l}\text { Genotypic } \\
\text { Variance }\end{array}$ & $\begin{array}{l}\text { Phenotypic } \\
\text { variance }\end{array}$ & $\begin{array}{c}\text { Genotypic } \\
\text { coefficient } \\
\text { of } \\
\text { variation } \\
(\%)\end{array}$ & $\begin{array}{c}\text { Phenotypc } \\
\text { coefficient of } \\
\text { variation (\%) }\end{array}$ & $\begin{array}{l}\text { Heritability } \\
\left(\mathrm{h}_{\mathrm{b})}^{2}\right.\end{array}$ & GA & GA\% \\
\hline $\begin{array}{l}\text { Days to } 1^{\text {st }} \\
\text { flowering }\end{array}$ & 229.65 & 234.35 & 16.04 & 16.20 & 97.99 & 30.90 & 32.71 \\
\hline $\begin{array}{l}\text { Days to } 50 \% \\
\text { flowering }\end{array}$ & 183.23 & 189.38 & 13.06 & 13.28 & 96.75 & 27.43 & 26.46 \\
\hline $\begin{array}{l}\text { Days to } 1^{\text {st }} \text { pod } \\
\text { setting }\end{array}$ & 171.07 & 175.88 & 11.84 & 12.00 & 97.27 & 26.57 & 24.05 \\
\hline $\begin{array}{c}\text { No. of } \\
\text { pods/plant }\end{array}$ & 2609.44 & 2611.54 & 64.58 & 64.60 & 99.92 & 105.19 & 132.98 \\
\hline 20-pod wt & 2808.13 & 2863.19 & 25.79 & 26.04 & 98.08 & 108.11 & 52.62 \\
\hline Pod yield/plant & 257310.37 & 257656.33 & 63.18 & 63.22 & 99.87 & $\begin{array}{c}1044.2 \\
5\end{array}$ & 130.07 \\
\hline Pod length & 5.85 & 7.63 & 23.36 & 26.68 & 76.64 & 4.36 & 42.13 \\
\hline $\begin{array}{l}\text { No. of seeds/ } \\
\text { pod }\end{array}$ & 0.36 & 1.03 & 13.88 & 23.33 & 35.40 & 0.74 & 17.01 \\
\hline $\begin{array}{l}\text { No. of seeds/ } \\
\text { plant }\end{array}$ & 46225.56 & 52412.7 & 62.98 & 67.06 & 88.20 & 415.94 & 121.3 \\
\hline 100-seed wt & 111.07 & 113.49 & 15.33 & 15.49 & 97.87 & 21.48 & 31.23 \\
\hline $\begin{array}{l}\text { Seed yield/ } \\
\text { plant }\end{array}$ & 23591.27 & 26506.4 & 66.39 & 70.37 & 89.00 & 298.50 & 129.01 \\
\hline
\end{tabular}

length indicated the importance of both additive and non-additive genetic effects for the control of this character. Selection for this character would, therefore, be moderately effective. Rahman (1989) observed fairly high $\mathrm{h}_{\mathrm{b}}{ }_{\mathrm{b}}$ for pod length with limited GCV. The high estimate of $\mathrm{h}^{2}{ }_{\mathrm{b}}(97.87 \%)$ and moderately high GA (31.23\%) of 100-seed weight indicated the importance of additive genetic effect for the control of this character. Raffi and Nath (2004) also found similar result in drybean. The PCV (64.60\%) for number of pods/plant was higher than the GCV (64.58\%). The difference between these parameters was nil suggesting environment had little or no role on the number of pods/plant for its expression. High $\mathrm{h}_{\mathrm{b}}^{2}(99.92 \%)$ and high GA (132.98\%) for this trait indicated the importance of additive genetic effect for the control of this character.The difference between genotypic and phenotypic coefficients of variation for pod yield/plant was virtually nil (Table 2) pointing little or no influence of environment on pod yield/plant. The high $\mathrm{h}_{\mathrm{b}}^{2}(99.87 \%)$ and high GA (130.07\%) for pod yield 
suggested that selection for this character would be effective. Rahman (1989) observed moderate $h^{2}{ }_{b}$ with high GCV for edible pod yield/plant. Heritability estimates may be of great help for selection on the basis of phenotypic performances. High heritability along with high expected genetic advance is usually more useful in predicting the resultant effect for selecting the best individuals than heritability alone (Johnson et al., 1955). Swarup and Chaugale (1962) observed that heritability was not always an indication of high genetic advance.

To have more clear understanding of the variation present in the experimental materials, variability parameters, such as range (min./max. values), overall mean, variance, and coefficient of variation were estimated for all the characters.

\section{Genotypic and phenotypic correlations}

Genotypic and phenotypic correlation coefficients among various characters are shown in Table 4. In most of the cases, the genotypic correlation coefficients were higher than the corresponding phenotypic correlation values, which suggested that the association of these characters had largely been influenced and regulated by genotypic cause rather than by environmental factors. In this investigation, pod yield showed moderately significant correlation coefficients with days to first flowering in genotypic level but non-significant positive correlation at phenotypic level. Rahman (2002) reported that pod yield/plant was positively and significantly correlated with days to first flowering. Number of pods/plant displayed significant positive correlation with seed yield/plant, number of seeds/plant and pod yield/plant at $1 \%$ level of probability at phenotypic and genotypic levels but negatively correlated with 20-pod weight, pod length, number of seeds/pod. 20-pod weight was positively correlated with pod yield/plant and pod length at both genotypic and phenotypic levels. Pod yield/plant showed strong significant positive correlation with number of seeds/plant and seed yield/plant at $1 \%$ level of probability. Again pod yield/plant had non-significant positive correlation with pod length and number of seeds/pod but significant negative correlation with100-seed weight at $5 \%$ level of probability. Number of seeds/plant was strongly and positively correlated with seed yield/plant at both genotypic and phenotypic levels, but negatively correlated with 100 -seed weight. Hundred-seed weight was positively correlated with seed yield/plant. Similar result was also found in dry bean by Raffi and Nath (2004).The result of the present study showed that days to $1^{\text {st }}$ flowering, number of pods/plant and 20-pod weight had highly significant positive correlation with pod yield/plant in both genotypic and phenotypic levels. Mishra et al. (1996) reported significant positive collation between seeds/pod and pod yield. 
Table 2. Maximum and minimum values of representing different characters of mean performance across 66 genotypes of

\begin{tabular}{|c|c|c|c|c|c|c|c|c|c|c|c|}
\hline Parameters & $\begin{array}{c}\text { Days to } \\
1^{\text {st }} \\
\text { flowering }\end{array}$ & $\begin{array}{c}\text { Days to } \\
50 \% \\
\text { flowering }\end{array}$ & $\begin{array}{l}\text { Days to } \\
1^{\text {st }} \text { pod } \\
\text { setting }\end{array}$ & $\begin{array}{l}\text { No. of } \\
\text { pods/ } \\
\text { plant }\end{array}$ & $\begin{array}{l}20 \text { pod wt } \\
\text { (g) }\end{array}$ & $\begin{array}{l}\text { Pod } \\
\text { yield/ } \\
\text { plant }\end{array}$ & $\begin{array}{l}\text { Pod } \\
\text { length } \\
(\mathrm{cm})\end{array}$ & $\begin{array}{c}\text { No. of } \\
\text { seeds/ } \\
\text { pod }\end{array}$ & $\begin{array}{l}\text { No. of } \\
\text { seeds/ } \\
\text { plant }\end{array}$ & $\begin{array}{c}100 \text {-seed } \\
\text { wt }\end{array}$ & $\begin{array}{l}\text { Seed } \\
\text { yield/ } \\
\text { plant }\end{array}$ \\
\hline $\begin{array}{l}\text { Maximum } \\
\text { value }\end{array}$ & $\begin{array}{c}119.33 \\
(\mathrm{DS}-118, \\
\mathrm{DS}-10 / \mathrm{B})\end{array}$ & $\begin{array}{c}131.00 \\
(\mathrm{DS}-118)\end{array}$ & $\begin{array}{c}141.67 \\
\text { (DS-118) }\end{array}$ & $\begin{array}{c}254.00 \\
\text { (DS-112) }\end{array}$ & $\begin{array}{c}377.67 \\
\text { (DS-99) }\end{array}$ & $\begin{array}{c}2049.35 \\
\text { (DS-151) }\end{array}$ & $\begin{array}{c}21.33 \\
\text { (DS-99) }\end{array}$ & $\begin{array}{c}6.00 \\
\text { (DS-19, } \\
\text { DS-99) }\end{array}$ & $\begin{array}{c}1035.67 \\
(\mathrm{DS}-151)\end{array}$ & $\begin{array}{c}83.33 \\
\text { (DSN- } \\
16)\end{array}$ & $\begin{array}{c}820.25 \\
\text { (DS-151) }\end{array}$ \\
\hline $\begin{array}{l}\text { Minimum } \\
\text { value }\end{array}$ & $\begin{array}{c}59.33 \\
(\mathrm{KBS}-7)\end{array}$ & $\begin{array}{c}64.33 \\
\text { (KBS-7) }\end{array}$ & $\begin{array}{c}71.00 \\
(\mathrm{KBS}-1 \times \\
\text { DS-167) }\end{array}$ & $\begin{array}{c}9.00 \\
(\mathrm{DS}-27)\end{array}$ & $\begin{array}{c}110.67 \\
(\mathrm{DS}-118)\end{array}$ & $\begin{array}{c}89.92 \\
(\mathrm{DS}-36)\end{array}$ & $\begin{array}{c}5.00 \\
\text { (DS-112) }\end{array}$ & $\begin{array}{c}2.67 \\
\text { (DS-113) }\end{array}$ & $\begin{array}{c}45.00 \\
(\mathrm{DS}-27)\end{array}$ & $\begin{array}{l}39.67 \\
\text { (DS- } \\
143)\end{array}$ & $\begin{array}{c}35.37 \\
\text { (DSN-27) }\end{array}$ \\
\hline LSD (.01) & 4.627 & 5. & 4.681 & 3.092 & 15.84 & 39.70 & 2.850 & 1.741 & 167.9 & 3.320 & 115.2 \\
\hline CV (\%) & 2.29 & 2.39 & 1.98 & 1.83 & 3.61 & 2.32 & 12.90 & 12.75 & 13.04 & 2.26 & 14.34 \\
\hline
\end{tabular}


Path analysis: Seed yield is a complex quantitative trait attributed by a number of other component traits. Although correlation studies provide information about yield attributes but do not give an exact picture of relative importance of direct and indirect influence of the related characters towards yield. So in order to ascertain a clear picture of the interrelationship, how the yield attributes exercise their impact on yield and which of them converge on yield directly and indirectly, path analysis has been worked out. Path coefficients based on both genotypic and phenotypic values of 10 important yield contributing characters on seed yield are presented in Table 4 and 5 . It appears that days to $1^{\text {st }}$ flowering, days to $50 \%$ flowering, days to $1^{\text {st }}$ pod setting, number of pods/plant, 20-pod weight, pod yield/plant, pod length, number of seeds/pod, number of seeds/plant, 100-seed weight influenced seed yield/plant directly in positive direction.

Days to first flowering: Analysis shows (Table 4 and 5) days to first flowering had positive direct effect on seed yield. Similar result was observed by Shinde and Dumbre (2001) in French bean. High positive indirect effects of days to first flowering on seed yield/plant was displayed through days to $50 \%$ flowering, number of pods/plant, 20-pod weight, pod yield/plant and number of seeds/plant. In spite of positive correlation with seed yield/plant, days to first flowering exhibited positive direct effect on seed yield, which had been offset by its positive and remarkable indirect effect on pod yield. But days to first flowering had negative and indirect correlation with days to $1^{\text {st }}$ pod setting, pod length, number of seeds/pod, and 100-seed weight.

Days to 50\% flowering: Days to 50\% flowering exhibited positive direct effect on seed yield/plant and it influenced the seed yield positively through its indirect effects via number of pods/plant, pod yield/plant, number of seeds/plant. But days to $50 \%$ flowering was negatively and indirectly correlated with days to $1^{\text {st }}$ pod setting, 20-pod weight, pod length, number of seeds/pod and 100-seed weight.

Days to $1^{\text {st }}$ pod setting: Days to first pod setting displayed negative direct effect on seed yield/plant and it influenced seed yield positively through indirect effects via days to $50 \%$ flowering, number of pods/plant, pod yield/plant, number of seeds/plant.

Number of pods/plant: Pods/plant had the $2^{\text {nd }}$ highest significant and positively direct effect on seed yield (0.466) and its correlation with seed yield was positive at the genotypic level. Positive direct effect on seed yield was also obtained by Rahman et al. (1988) in Lablab purpureus. The negative indirect effects of pods/plant on seed yield via days to first pod setting, pod length, 20green pod weight, number of seeds/pod, and 100-seed weight reduced the correlation value. 
Table 3. Genotypic(G) and phenotypic(P) correlation coefficients among 11 characters estimated from 66 genotypes of lablab bean.

\begin{tabular}{|c|c|c|c|c|c|c|c|c|c|c|c|}
\hline Characters & $\begin{array}{c}\text { Correlation } \\
\text { (G\& P) }\end{array}$ & \begin{tabular}{|c|} 
Days to \\
$50 \%$ \\
flowering
\end{tabular} & $\begin{array}{l}\text { Days to } \\
1^{\text {st }} \text { pod } \\
\text { setting }\end{array}$ & $\begin{array}{l}\text { No. of } \\
\text { pods } \\
\text { /plant }\end{array}$ & $\begin{array}{l}20 \text { pod } \\
\text { wt (g) }\end{array}$ & $\begin{array}{l}\text { Pod yield } \\
\text { /plant (g) }\end{array}$ & $\begin{array}{l}\text { Pod } \\
\text { length } \\
(\mathrm{cm})\end{array}$ & $\begin{array}{c}\text { No. of } \\
\text { seeds / } \\
\text { pod }\end{array}$ & $\begin{array}{l}\text { No. of } \\
\text { seeds } \\
\text { /plant }\end{array}$ & $\begin{array}{c}\text { 100-seed } \\
\text { wt (g) }\end{array}$ & $\begin{array}{c}\text { Seed } \\
\text { yield } \\
\text { /plant (g) }\end{array}$ \\
\hline Days to $1^{\text {st }}$ & G & $0.960 * *$ & $0.879 * *$ & 0.134 & 0.055 & $0.182^{*}$ & -0.131 & -0.060 & 0.097 & $-0.238 * *$ & 0.080 \\
\hline flowering & $\mathrm{P}$ & $0.958^{* *}$ & $0.876 * *$ & 0.131 & 0.050 & $0.179 *$ & -0.128 & -0.046 & 0.099 & $-0.236 * *$ & 0.082 \\
\hline Days to $50 \%$ & G & & $0.898 * *$ & 0.126 & -0.032 & 0.121 & -0.173 & -0.036 & 0.089 & $-0.262^{* *}$ & 0.064 \\
\hline flowering & $\mathrm{P}$ & & $0.897 * *$ & 0.122 & -0.030 & 0.119 & $-0.178 *$ & -0.035 & 0.088 & $-0.259 * *$ & 0.063 \\
\hline Days to $1^{\text {st }}$ & G & & & 0.075 & -0.087 & 0.058 & $-0.199 *$ & -0.107 & 0.035 & $-0.230 * *$ & 0.008 \\
\hline pod setting & $\mathrm{P}$ & & & 0.071 & -0.088 & 0.056 & $-0.198 *$ & -0.096 & 0.036 & $-0.229 * *$ & 0.006 \\
\hline \multirow[t]{2}{*}{ No. of pods/plant } & G & & & & -0.073 & $0.877 * *$ & -0.118 & -0.071 & $0.955^{* *}$ & -0.168 & $0.918^{* *}$ \\
\hline & $\mathrm{P}$ & & & & -0.069 & $0.865^{* *}$ & -0.112 & -0.067 & $0.948 * *$ & -0.158 & $0.912^{* *}$ \\
\hline \multirow[t]{2}{*}{20 pod wt (g). } & G & & & & & $0.355^{* *}$ & $0.302^{* *}$ & 0.122 & -0.015 & 0.017 & -0.005 \\
\hline & $\mathrm{P}$ & & & & & $0.348 * *$ & $0.298^{* *}$ & 0.119 & -0.014 & 0.015 & -0.004 \\
\hline \multirow[t]{2}{*}{ Pod yield/plant (g) } & G & & & & & & 0.070 & 0.023 & $0.877 * *$ & $-0.175^{*}$ & $0.837 * *$ \\
\hline & $\mathrm{P}$ & & & & & & 0.069 & 0.021 & $0.871^{* *}$ & $-0.174^{*}$ & $0.832 * *$ \\
\hline \multirow[t]{2}{*}{ Pod length (cm) } & G & & & & & & & $0.375^{* *}$ & -0.007 & 0.075 & -0.001 \\
\hline & $\mathrm{P}$ & & & & & & & $0.340^{* *}$ & -0.007 & 0.074 & -0.0008 \\
\hline \multirow{2}{*}{ No. of seeds /pod } & G & & & & & & & & 0.098 & 0.088 & 0.110 \\
\hline & $\mathrm{P}$ & & & & & & & & $0.201 *$ & 0.084 & $0.208^{*}$ \\
\hline \multirow[t]{2}{*}{ No. of seeds /plant } & G & & & & & & & & & -0.149 & $0.937 * *$ \\
\hline & $\mathrm{P}$ & & & & & & & & & -0.148 & $0.965^{* *}$ \\
\hline \multirow[t]{2}{*}{100 seed wt (g). } & G & & & & & & & & & & 0.084 \\
\hline & $\mathrm{P}$ & & & & & & & & & & 0.081 \\
\hline
\end{tabular}

$* \mathrm{P}<0.05 ; * * \mathrm{P}<0.01$ 
Table 4. Path coefficient analysis (on genotypic values) showing direct effect (bold) and indirect effects of 11 characters on pod yield in lablab bean.

\begin{tabular}{|c|c|c|c|c|c|c|c|c|c|c|c|}
\hline Characters & $\begin{array}{c}\text { Days to } \\
1^{\text {st }} \\
\text { flowering }\end{array}$ & $\begin{array}{c}\text { Days to } \\
50 \% \\
\text { flowering }\end{array}$ & $\begin{array}{l}\text { Days to } \\
1^{\text {st }} \text { pod } \\
\text { setting }\end{array}$ & $\begin{array}{c}\text { No. of } \\
\text { pods/ } \\
\text { plant }\end{array}$ & $\begin{array}{l}20 \text { pod } \\
\text { wt (g) }\end{array}$ & $\begin{array}{c}\text { Pod } \\
\text { yield/ } \\
\text { plant (g) }\end{array}$ & $\begin{array}{l}\text { Pod } \\
\text { length } \\
(\mathrm{cm})\end{array}$ & $\begin{array}{c}\text { No. of } \\
\text { seeds } \\
\text { /pod }\end{array}$ & $\begin{array}{c}\text { No. of } \\
\text { seeds/ } \\
\text { plant }\end{array}$ & $\begin{array}{l}\text { 100-seed } \\
\text { wt (g) }\end{array}$ & $\begin{array}{c}\text { Seed } \\
\text { yield/plant } \\
\text { (g) }\end{array}$ \\
\hline $\begin{array}{l}\text { Days to } 1^{\text {st }} \\
\text { flowering }\end{array}$ & 0.041 & 0.0057 & -.018 & 0.0624 & 0.00078 & 0.0014 & -0.0016 & -0.004 & 0.050 & -0.057 & 0.080 \\
\hline $\begin{array}{c}\text { Days to } 50 \% \\
\text { flowering }\end{array}$ & 0.0392 & 0.0059 & -0.0186 & 0.0586 & -0.0005 & 0.0009 & -0.0021 & -0.0024 & 0.045 & -0.063 & 0.064 \\
\hline $\begin{array}{l}\text { Days to } 1^{\text {st }} \\
\text { pod setting }\end{array}$ & -0.036 & 0.0053 & -0.021 & 0.035 & -0.0123 & 0.0005 & -0.0025 & -0.0070 & 0.018 & -0.055 & 0.008 \\
\hline $\begin{array}{c}\text { No. of pods/ } \\
\text { plant }\end{array}$ & 0.0055 & 0.00074 & -0.0016 & 0.466 & -0.0010 & 0.0068 & -0.0015 & -0.0047 & 0.488 & -0.0402 & $0.918^{* *}$ \\
\hline 20 pod wt. (g) & 0.0022 & -0.0002 & 0.0018 & -0.034 & 0.0142 & 0.0028 & 0.0037 & 0.008 & -0.0077 & 0.0041 & -0.005 \\
\hline $\begin{array}{l}\text { Pod yield/ } \\
\text { plant (g) }\end{array}$ & 0.0074 & 0.0007 & -0.0012 & 0.409 & 0.0051 & 0.0078 & 0.0009 & 0.0015 & 0.448 & -0.042 & $0.837 * *$ \\
\hline $\begin{array}{l}\text { Pod length } \\
\text { (cm) }\end{array}$ & -0.0054 & -0.0010 & 0.0041 & -0.055 & 0.0043 & 0.0004 & 0.0123 & 0.025 & -0.0036 & 0.0179 & -0.001 \\
\hline $\begin{array}{c}\text { No. of seeds/ } \\
\text { pod }\end{array}$ & -0.0025 & -0.0002 & 0.0022 & -0.033 & 0.00173 & 0.00018 & 0.0046 & 0.066 & 0.0500 & 0.0211 & 0.110 \\
\hline $\begin{array}{l}\text { No. of seeds/ } \\
\text { plant }\end{array}$ & 0.0040 & 0.0005 & -0.0007 & 0.445 & -0.0002 & 0.0068 & -0.0001 & -0.0065 & 0.511 & -0.0356 & $0.937 * *$ \\
\hline $\begin{array}{c}\text { 100-seed wt } \\
\text { (g) }\end{array}$ & 0.0097 & -0.0016 & 0.0048 & -0.078 & 0.0002 & -0.0014 & 0.0009 & 0.0058 & -0.0761 & 0.239 & 0.084 \\
\hline
\end{tabular}

Note: Bold and diagonal figures indicate direct effect; Residual effect: 0.056258 
Table 5. Path coefficient analysis (on phenotypic values) showing direct effect (bold) and indirect effects of 11 characters on pod $\stackrel{\sqcup}{\triangleright}$ yield in lablab bean.

\begin{tabular}{|c|c|c|c|c|c|c|c|c|c|c|c|}
\hline Characters & $\begin{array}{l}\text { Days to } 1^{\text {st }} \\
\text { flowering }\end{array}$ & $\begin{array}{c}\text { Days to } \\
50 \% \\
\text { flowering }\end{array}$ & $\begin{array}{c}\text { Days to } \\
1^{\text {st }} \text { pod } \\
\text { setting }\end{array}$ & $\begin{array}{c}\text { No .of } \\
\text { pods/plant }\end{array}$ & $\begin{array}{l}20 \text { pod } \\
\text { wt (g) }\end{array}$ & $\begin{array}{l}\text { Pod } \\
\text { yield/ } \\
\text { plant } \\
\text { (g) }\end{array}$ & $\begin{array}{l}\text { Pod } \\
\text { length } \\
(\mathrm{cm})\end{array}$ & $\begin{array}{c}\text { No. of } \\
\text { seeds/pod }\end{array}$ & $\begin{array}{c}\text { No. of } \\
\text { seeds/ } \\
\text { plant }\end{array}$ & $\begin{array}{c}100- \\
\text { seed wt } \\
\text { (g) }\end{array}$ & $\begin{array}{c}\text { Seed } \\
\text { yield/ } \\
\text { plant (g) }\end{array}$ \\
\hline $\begin{array}{l}\text { Days to } 1^{\text {st }} \\
\text { flowering }\end{array}$ & 0.0713 & 0.0123 & -0.0396 & 0.0032 & 0.0019 & -0.0165 & 0.0003 & 0.0012 & 0.105 & -0.0566 & 0.082 \\
\hline $\begin{array}{l}\text { Days to } 50 \% \\
\text { flowering }\end{array}$ & 0.0683 & 0.0128 & -0.0405 & 0.0030 & -0.001 & -0.011 & 0.0038 & 0.0009 & .093 & -0.063 & 0.063 \\
\hline $\begin{array}{l}\text { Days to } 1^{\text {st }} \\
\text { pod setting }\end{array}$ & 0.0625 & 0.0115 & -0.0452 & 0.0018 & -0.0032 & -0.0053 & 0.00042 & 0.0024 & 0.0038 & -0.055 & 0.008 \\
\hline $\begin{array}{l}\text { No. of pods/ } \\
\text { plant }\end{array}$ & 0.0096 & 0.0016 & -0.0034 & 0.0239 & -0.0026 & -0.0798 & 0.0002 & 0.0017 & 1.001 & -0.0403 & $0.912^{* *}$ \\
\hline $\begin{array}{l}20 \text { pod wt } \\
\text { (g) }\end{array}$ & 0.0039 & -0.0004 & 0.0040 & -0.0017 & 0.0359 & -0.032 & -0.0006 & -0.0030 & -0.015 & 0.0041 & -0.005 \\
\hline $\begin{array}{l}\text { Pod yield/ } \\
\text { plant (g) }\end{array}$ & 0.0129 & 0.0016 & -0.0026 & 0.0201 & 1.274 & -0.0910 & -0.0002 & -0.0005 & 0.919 & -0.042 & $0.832 * *$ \\
\hline $\begin{array}{l}\text { Pod length } \\
\text { (cm) }\end{array}$ & -0.009 & -0.0023 & 0.0089 & -0.0028 & 0.0108 & -0.006 & -0.0021 & -0.0085 & -0.0074 & 0.0178 & -0.0008 \\
\hline $\begin{array}{l}\text { No. of seeds/ } \\
\text { pod }\end{array}$ & -0.0034 & -0.0005 & 0.0043 & -0.0016 & 0.0043 & -0.0019 & -0.0007 & -0.0249 & 0.2123 & 0.0202 & $0.208 *$ \\
\hline $\begin{array}{c}\text { No. of seeds/ } \\
\text { plant }\end{array}$ & 0.0071 & 0.0011 & -0.0016 & 0.0227 & -0.0005 & -0.0793 & 0.00001 & -0.0050 & 1.056 & -0.0355 & $0.965 * *$ \\
\hline $\begin{array}{c}\text { 100-seed wt } \\
\text { (g) }\end{array}$ & -0.0168 & -0.0034 & 0.0104 & -0.0040 & 0.0006 & 0.0158 & -0.0002 & -0.0021 & -0.1563 & 0.2399 & 0.084 \\
\hline
\end{tabular}

Note: Bold and diagonal figures indicate direct effect, Residual effect 0.013738 . 
20-pod weight: 20-pod weight exhibited high positive direct effect on seed yield/plant and its correlation with seed yield was negative and insignificant. It had negative indirect effect on seed yield via days to $50 \%$ flowering, number of pods/plant and number of seeds/plant.

Pod yield/plant: Pod yield/plant showed positive direct effect on seed yield and its correlation with seed yield was positive and highly significant $(\mathrm{P}<0.01)$. But it had negative indirect effect on seed yield via days to $1^{\text {st }}$ pod setting and 100 seed weight.

Pod length: Pod length had positive direct effect on seed yield and its correlation with seed yield was moderate. Nandi et al. (1999) observed that pod length had high positive direct effect on pod yield. It contributed positively to seed yield through its indirect effects via days to first pod setting, 20-green pod weight, pod yield/plant, number of seeds/pod and 100-seed weight.

No. of seeds/pod: Number of seeds/pod showed positive direct effect on seed yield and its correlation with seed yield was also positive. But the trait had negative indirect effects of days to $1^{\text {st }}$ flowering, days to $50 \%$ flowering and number of pods/plant.

No. of seeds/plant: Number of seeds/plant had the highest positive direct effect on seed yield (0.511) and its correlation with seed yield was positive and highly significant at $1 \%$ level of probability. The character had negative indirect effects of days to first pod setting, 20-pod weight, pod length, number of seeds/pod and 100-seed weight.

100-seed weight: Hundred-seed weight showed positive direct effect on seed yield/plant. Its correlation with seed yield was positively, but the negative indirect effects of 50\% flowering, number of pods/plant, pod yield/plant and number of seeds/plant reduced its correlation value with seed yield. On the whole, path coefficients indicated that days to $1^{\text {st }}$ flowering, days to $50 \%$ flowering, number of pods/plant, 20-pod weight, pod yield/plant, pod length, number of seeds/pod, number of seeds/plant ,100-seed weight seed yield/plant were the most important yield contributing characters. They contributed to pod yield and seed yield directly in positive direction. These nine characters considered as primary yield components in climbing genotypes of lablab bean. Therefore, selection based on these characters would bring about good effect on pod yield and seed yield.

\section{References}

Ali, F., B. Sikdar, A. K. Roy and O. I. Joarder. 2005. Correlation and genetic variation of twenty different genotypes of lablab bean [Lablab purpureus (L.) Sweet] Bangladesh. J. Bot. 34(2): 125-128. 
Bullivant, S. H. 1963. Farm crops. Book one. Rural Education Longmans Green and Co. London, P. 10.

Chakravarty, A. K. 1986. Dolichos bean. Pp. 524-528. In: vegetable crops in India. T.K. Boss and M. G. Som (ed) Naya prokash, Calcutta, India, 775 P.

Chowdhury, A. R., M. Ali, and M. A. Quadir. 1989. Aspects of pollination and floral biology of lablab bean (Lablab purpureus L. Sweet). J. of the Japanese Society for Horticultural Sci. 58(3): 665-71. Pl. Br. Abstr. 60(12): 1567.

Chowdhury, A. R., M. Ali, M. A. Qurdir and A.H. Talukder. 1989. Floral biology of hyacinth bean (L. purpureus L. Sweet). Thai J. Agric. Sci. 22: 56-67.

CFLIP (Coordinated Food Legume Improvement Project).1988. Annual Report for 198788, Report number 1:51-74.

Chandel, K. P. S. 1983. Path co-efficient analysis of yield components in green seeded pea. SABRAO J. 15(1): 55-64.

Johnson, K.F. and R.E.Comstoc. 1955. Genotypic and phenotypic correlation in rapeseed and implications in selection. Agron. J. 47(10): 477-483

Kabir, J and S. Sen. 1987. Studies on genetic variability and heritability in Dolichos bean. Annals of Agril. Res. 8(1): 141-144.

Katyal, S. L. and K. L. Chandha. 1988.Vegetable growing in India. 2nd Ed. Oxford and IBH publishing Co., New Delhi-110020, P. 68.

Mishra, H. N., B. Killadi and R. C. Mishra. 1996. Character association and path coefficient analysis in pole type French bean. Environ and Ecol. 14(1): 103-106.

Nahar, K., M. A. Newaz. 2005. Genetic variability, character association and path analysis in lablab bean (Lablab purpureus L.). International J. of Sustainable Agril. Tech. 1(6): 35-40.

Nandi, A., P. Tripathy and D. Hencha. 1999. Character association, path analysis and selection indices in brown seeded pole French bean (Phaseolus vulgaris). Egyptian J. of Horticulture 26 (1):59-66.

Nath, P. 1976. Vegetables for the tropical region. ICAR. New Delhi, P. 40.

Nath, P. 1976. Vegetables for the Tropical Region, ICAR, New Delhi, (cited from vegetable crops in India. Ed. Bose. T.K., Som, M.G. 1986). Naya Prokash, Calcutta6, P. 525.

Purseglove, J.W. 1977. Tropical corps. In: Dicotyledons. Longman, London, Pp. 273-276.

Raffi, S. A. and Nath. U.K. 2004. Variability, heritability, genetic advance and relationships of yield and yield contributing characters in dry bean (Phaseolus vulgaris.). J. of Biological Sciences 4(2): 157-159.

Rahman, S. 2002. Growth physiology and character association in dwarf and climbing genotypes of lablab bean. M.Sc (Ag.). Thesis, Genet. and Plant Breed. Dept., Bangladesh Agric. Univ., Mymensingh

Robinson, H. F., R. E. Comstock, and P. H. Harvey. 1949. Estimation heritability and degree of dominance in corn. Agron. J. 41: 353-359. 
Rahman, M. M. 1989. Study of genetic variation and heterosis in lablab bean. M. Sc. (Ag.) Thesis, Genet. and Plant Breed. Dept., Bangladesh Agric. Univ., Mymensingh.

Rahman, M. M., F.L. Alam, K. M. Kabir and M. A. Quasem. 1988. Genetic parameters and character association in hyacinth bean (L. purpureus L. Sweet). Bangladesh J. Plant Breed. and Genet. 1\&2: 123-128.

Shinde, S. S. and A. D. Dumbre. 2001. Correlation and path coefficient analysis in French bean. J. of Maharashtra Agri. Univ. 26 (1): 48-49.

Swarup,V. and D.S. Chaugale. 1962. Studies on genetic variability in sorghum. Phenotypic variation and its heritable components in some important quantitative characters contributing towards yield. Indian J. Genet. 22: 31 -36.

Yamaguchi, M. 1983. World vegetables, principles, production and nutritive values. The AVI Publishing Co., USA, Pp. 278-297. 